Review

\title{
The Potential of Cyclodextrins as Novel Active Pharmaceutical Ingredients: A Short Overview
}

\author{
Massimiliano Pio di Cagno \\ Drug Transport and Delivery Research Group, Department of Pharmacy, University of Troms $\varnothing$, \\ The Arctic University of Norway, 9019 Tromsø, Norway; massimiliano.p.cagno@uit.no; Tel.: +47-77-645-301 \\ Academic Editor: Bernard Martel \\ Received: 10 November 2016; Accepted: 16 December 2016; Published: 25 December 2016
}

\begin{abstract}
Cyclodextrins (CDs) are cyclic oligosaccharides of natural origin that were discovered more than 100 years ago. The peculiar cone-like conformation of the sugar ring, expressing a lipophilic cavity and a hydrophilic external surface, allows these substances to spontaneously complex poorly soluble compounds in an aqueous environment. For more than 50 years, these substances have found applicability in the pharmaceutical and food industries as solubilizing agents for poorly soluble chemical entities. Nowadays, several research groups all over the world are investigating their potential as active pharmaceutical ingredients (APIs) for the treatment of several illnesses (e.g., hypercholesterolemia, cancer, Niemann-Pick Type $C$ disease). The aim of this review is to briefly retrace cyclodextrins' legacy as complexing agents and describe the current and future prospects of this class of chemical entities in pharmaceutics as new APIs.
\end{abstract}

Keywords: cyclodextrins; inclusion complexes; solubilizing agents; cytotoxic activity; hypocholesterolemic agents; Niemann-Pick Type $\mathrm{C}$ disease treatment

\section{Cyclodextrin Types and Characteristics}

Cyclodextrins (CDs) are chemical entities of natural origin, which are derived from bacterial degradation of starch through the metabolic action of cyclodextrin glycosyl transferase enzyme (GCTase). This peculiar enzyme is present in several species of alkalophilic bacillus species (e.g., Bacillus macerans [1]) and it is capable of catalyzing the synthesis of cyclic oligosaccharides, starting from amylose. The general structure of CDs is based on $\alpha$-D-glucopyranose units linked $1 \rightarrow 4$, as in amylose. Three ring-types are common, where alpha-cyclodextrin $(\alpha \mathrm{CD})$ is composed of six, beta-cyclodextrin of seven $(\beta C D)$, and gamma-cyclodextrin of eight glucose units $(\gamma C D)$. All CDs are shaped as trunked cones (Figure 1A), expressing a hydrophobic inner cavity and an external hydrophilic surface. Even though the chemical structure of CDs may appear rather simple, the complete characterization and understanding of CDs chemical properties and geometrical three-dimensional conformations was a research enterprise, which required more than half a century to be completed [2]. The first isolation of cyclodextrins was made in 1891 by Antoine Villiers, but it took more than 50 years to obtain the correct characterization of cyclohexaamylose $(\alpha C D)$ and cycloheptaamylose ( $\beta C D$ ) molecular weighs [3]. The basic physicochemical characteristics of $\alpha-$, $\beta-$, and $\gamma \mathrm{CDs}-$ including a detailed description of cavity sizes and, for the first time, inclusion of complex formation tendency-was first published in 1954 by Friedrich Cramer [2,4]. Subsequently, Pulley and French [5] discovered bigger cyclodextrins composed of $9(\delta C D), 10(\varepsilon C D)$, and 11 ( $\zeta C D)$ glucose units (Figure 1C). At present, cyclodextrins containing up to 31 glucose units have been purified and characterized and the existence of even larger cyclodextrins containing up to several hundreds of glycosyl units have been reported [6]. The most important physicochemical properties of $\alpha-, \beta-$, and $\gamma$ CDs (most relevant CDs) are reported in Table 1. 
A

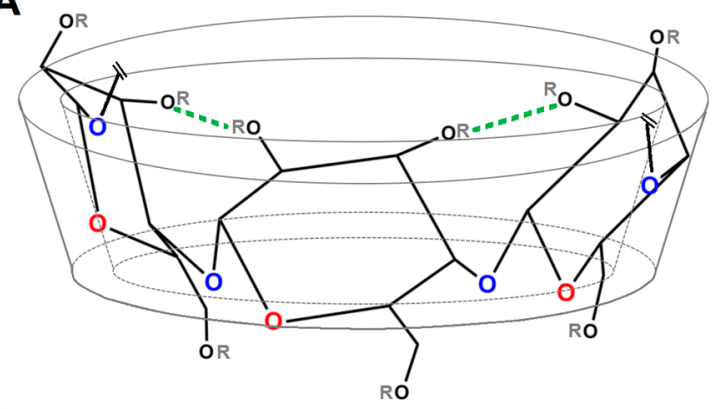

C

\begin{tabular}{|c|c|c|c|}
\hline Nomenclature & Abbreviation & $\begin{array}{c}\text { Number of } \\
\text { pyranose units }\end{array}$ & $\mathbf{R}$ \\
\hline a-cyclodextrin & aCD & 6 & $-\mathrm{H}$ \\
\hline$\beta$-cyclodextrin & $\beta C D$ & 7 & $-H$ \\
\hline Methyl- $\beta$-cyclodextrin & $M \beta C D$ & 7 & $-\mathrm{CH}_{3}$ \\
\hline Hydroxypropyl- $\beta$-cyclodextrin & HPBCD & 7 & $-\mathrm{CH}_{2} \mathrm{CH}(\mathrm{OH}) \mathrm{CH}_{3}$ \\
\hline sulfobutyl-ether- $\beta$-cyclodextrin & $S B E \beta C D$ & 7 & $-\left(\mathrm{CH}_{2}\right)_{4} \mathrm{SO}_{3}-\mathrm{Na}^{+}$ \\
\hline Y-cyclodextrin & YCD & 8 & $-H$ \\
\hline Hydroxypropyl-y-cyclodextrin & yCD & 8 & $-\mathrm{CH}_{2} \mathrm{CH}(\mathrm{OH}) \mathrm{CH}_{3}$ \\
\hline ס-cyclodextrin & $\delta C D$ & 9 & $-H$ \\
\hline$\varepsilon$-cyclodextrin & $\varepsilon C D$ & 10 & $-H$ \\
\hline$\zeta$-cyclodextrin & $\zeta C D$ & 11 & $-H$ \\
\hline
\end{tabular}

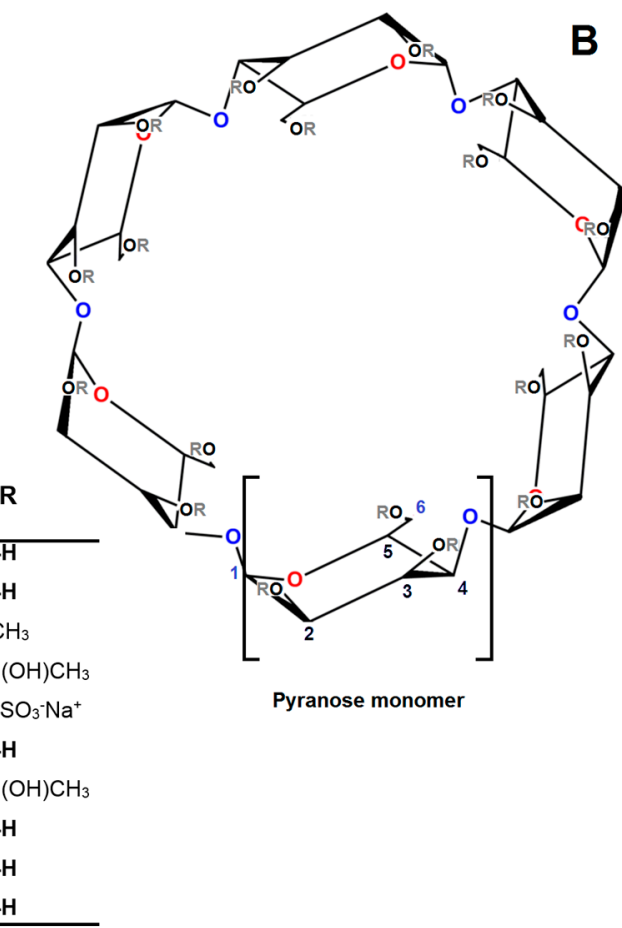

B

Figure 1. Front side prospect (A); top prospect (B); nomenclature and chemical characteristics (C) of most common cyclodextrins. The blue oxygens represent the etheric bonds 1-4 (inter-monomeric bonds), whereas, the red oxygens represents pyranose ether bonds $1-5$ (intra-monomeric bonds). The green lines represent the intramolecular H-bonds forming in $\beta C D$ when no substituent groups are present (R: $-\mathrm{H})$.

Table 1. Some physicochemical properties of the most relevant CDs $(\alpha-, \beta-$, and $\gamma \mathrm{CD})$ at $25{ }^{\circ} \mathrm{C}$.

\begin{tabular}{cccc}
\hline & $\alpha \mathrm{CD}$ & $\beta \mathrm{CD}$ & $\gamma \mathrm{CD}$ \\
\hline Cavity diameter $(\AA)$ & $\approx 5.2$ & $\approx 6.6$ & $\approx 8.4$ \\
Cavity volume $\left(\AA^{3}\right)$ & 100 & 160 & 250 \\
Water molecules in the cavity $\left(\mathrm{n}^{\mathrm{r}}\right)$ & 2.5 & 5.0 & 8.5 \\
Aqueous solubility $(\mathrm{M})$ & 0.12 & 0.016 & 0.17 \\
Gibbs free energy of dissolution $(\mathrm{kJ} / \mathrm{mol})$ & 15 & 20 & 14 \\
\hline
\end{tabular}

As it can be seen, aqueous solubility of cyclic saccharides is much lower in comparison to similar acyclic sugar molecules. The reason of that is found in the high energy of crystal lattice owned by cyclic saccharides when in a solid state. Among the three most investigated CDs, $\beta C D$ has the lowest solubility in water (approx. $0.016 \mathrm{M}$ at $25^{\circ} \mathrm{C}$ ), followed by $\alpha \mathrm{CD}(0.12 \mathrm{M})$ and $\gamma \mathrm{CD}(0.17 \mathrm{M})$ [7]. It is quite interesting to see that $\beta C D$ shows significantly less water solubility with respects to similar cyclic saccharides. This phenomenon is connected to intramolecular hydrogen bond formation between the hydroxyl groups of neighboring glucose units [8], as shown in Figure 1. This is reflected in the higher Gibbs free energy of dissolution owned by $\beta C D$ in comparison to others (Table 1). Even though the hepta-pyranose ring results in poor aqueous solubility, the cavity diameter ( 6 to $6.5 \AA$ ) is of optimal size to accommodate a vast majority of chemical entities [9]. To increase the poor aqueous solubility of $\beta C D$, several derivatives have been synthetized substituting hydroxyl groups with other hydrophilic moieties such as sulfobutyl ether- (SBE $\beta C D$ ) and hydroxypropyl groups (HP $\beta C D)$ (Figure 1C). The introduction of methyl groups $(\mathrm{M} \beta C D$ ) also proved to be very efficient in increasing aqueous solubility of $\beta C D$ due to the breakage of intramolecular hydrogen bonds [10]. Recently, polymeric derivatives of $\beta C D$ s such as polyethylene glycol- ( $\beta C D-P E G)$ and dextran- $\beta C D$ ( $\beta C D$-dextran) have been developed to achieve higher aqueous solubility $[11,12]$. 


\section{Inclusion Complex Formation and Its Investigation}

When cyclodextrins (the ligand, L) are in aqueous solution together with compatible molecules (the substrate, S), they will spontaneously interact forming an inclusion complex (Figure 2).

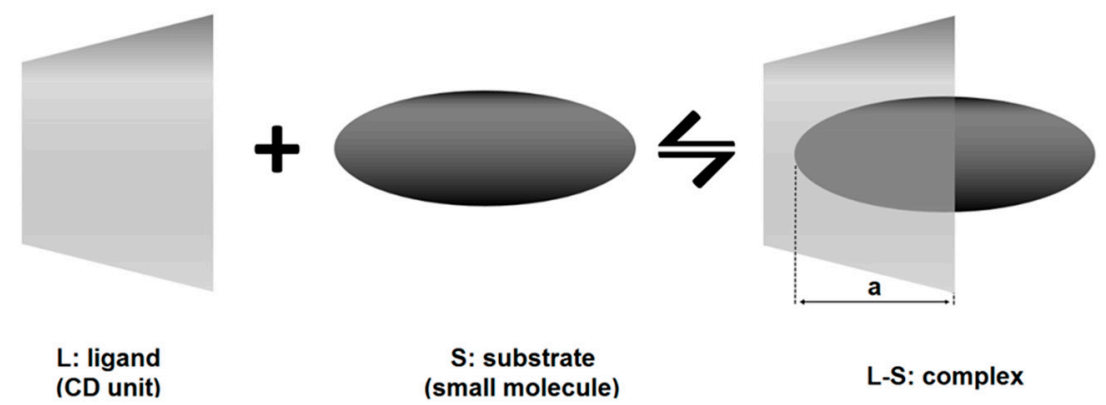

Figure 2. Schematic representation of the inclusion mechanism of complexation between CD (the ligand, L) and a small molecule (the substrate, S) in the case of 1:1 stoichiometry (molar ratio). The depth (a) that the substrate molecule can reach in the CD cavity varies according to the substrate physicochemical properties and CD steric hindrance.

If the stoichiometry of the complexation is 1:1 (Figure 2), the complexation equilibrium and its stability constant are expressed as:

$$
\begin{aligned}
& S+L \stackrel{K_{11}}{\leftrightarrow} S L \\
& K_{11}=\frac{[S L]}{[S][L]}
\end{aligned}
$$

where $S L$ represents the complex formed between substrate and ligand and $K_{11}$ the stability constant of the complex (generally expressed in $\mathrm{M}^{-1}$ ).

From the thermodynamic point of view, the Gibbs free energy $\left(\Delta G^{0}\right)$ of complexation results are:

$$
\Delta G^{0}=-R T \ln K_{11}=\Delta H^{0}-T \Delta S^{0}
$$

where $R$ is the gas constant, $T$ is the absolute temperature, $\Delta H^{0}$ is the standard enthalpy of complexation, and $\Delta S^{0}$ is the standard entropy of complexation. The driving forces of spontaneous complexation are primarily the formation of non-ionic interaction (e.g., van der Waals interactions, hydrogen bonds formation) between the CD cavity and the binding site of the substrate (resulting in negative standard enthalpy) and the solvent effect (resulting in either positive or negative standard entropy) [13]. For the three most common CDs, $K_{11}$ values vary from $0.1 \mathrm{M}^{-1}$ for very weak interactions, up to $1,000,000 \mathrm{M}^{-1}$ for very stable complexations. Moreover, $\alpha_{-}, \beta-$, and $\gamma \mathrm{CDs}$ appear to be quite alike in their complexation abilities [14]. Unfortunately, standard $\beta C D$ is of poor aqueous solubility (Table 1). Therefore, its direct usability is limited. Common techniques used to investigate the stability of the complex cyclodextrin-substrate are calorimetric analysis [15,16], nuclear magnetic resonance (NMR) [17,18], X-ray diffraction [19], and computational modelling [20]. An alternative classical method widely used to investigate the efficiency of CDs complexation with APIs is phase-solubility study [21,22]. This method is based on the paradigm that, if the $\mathrm{CD}$ is complexing a ligand in solution, this will result in solubilization of the API (i.e., higher apparent aqueous solubility of the substrate). Figure 3 shows all different types of phase solubility diagrams obtainable for CD complexation and solubilization of substrates. 


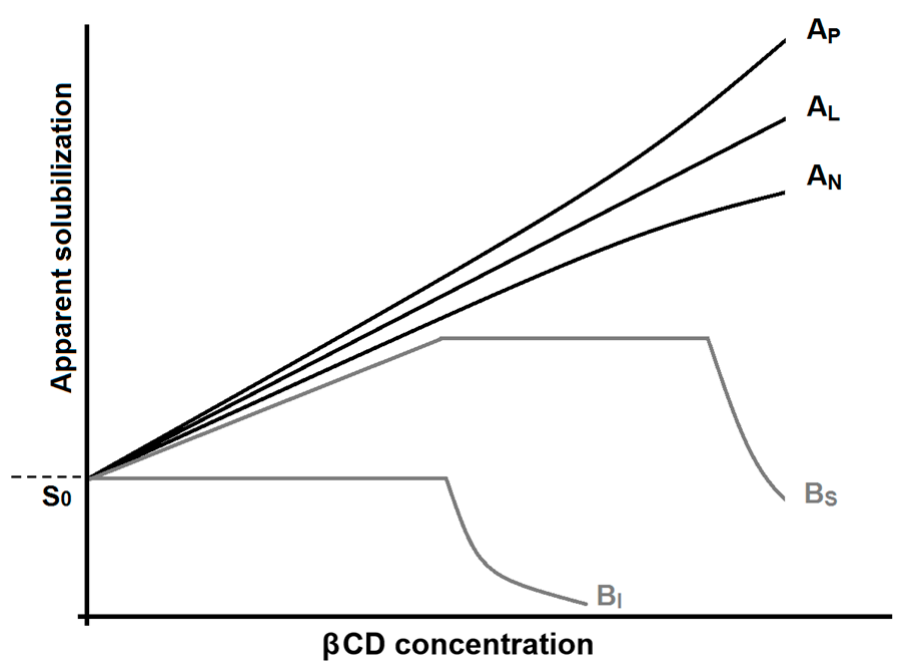

Figure 3. Phase-solubility diagrams associated with CDs. $S_{0}$ represents the thermodynamic solubility of the chemical entity in the absence of CDs. If complexation is effective and the complex formed results water-soluble, the substrates' apparent solubility increases (A types). If the complexation is inefficient or the complex formed is poorly soluble, the solubility of the substrate decreases (B type).

When there is a linear dependence between the substrate (i.e., API molecule) concentration and the ligand (i.e., $C D$ ) concentration, the graphs are generally defined as $A_{L}$ type [22]. In this case, the relation between concentration of $\mathrm{CD}$ and the API results in a linear regression. From this type of graph, knowing the thermodynamic solubility of the substrate $\left(S_{0}\right)$ and the slope of the linear regression, it is possible to estimate the equilibrium constant employing Equation (4) [13]:

$$
K_{1: 1}=\frac{(\text { slope })}{s_{0}(1-\text { slope })}
$$

Phase-solubility study is a very efficient method for the evaluation of cyclodextrin solubilization of a substrate (i.e., increasing of apparent solubility of an API, Figure 3) but it shows limitations in stability constant determination [23]. Moreover, the choice of the condition of the aqueous media of complexation (e.g., $\mathrm{pH}$, tonicity) is crucial for a correct estimation of $K_{1: 1}$ with this technique. For instance: in Figure 4, the phase-solubility diagram of ibuprofen (IBU, API commonly used as model drug for complexation studies $[17,24,25]$ ) in the presence of $\beta C D$ is reported as an example. From Figure 4, it is clear that $\mathrm{pH}$ of the experiment has a huge impact on the phase-solubility profile of IBU and, consequently, on the equilibrium constant. In the case of IBU at pH 3.8 (Figure 4A), the calculated $K_{1: 1}$ results are $7.9 \times 10^{3} \mathrm{M}^{-1}$ (in good agreement with ITC data reported in the literature [17]). However, for the same complexation in neutral $\mathrm{pH}$ (Figure 4B), the equilibrium constant results calculated from the phase-solubility diagram are almost three orders of magnitude lower. Deviation from the linearity in a phase-solubility diagram indicates a deviation from a 1:1 stoichiometry of reaction. The deviation from linearity can be positive $\left(A_{P}\right)$ or negative $\left(A_{N}\right)$ (Figure 3). A positive or negative deviation form linearity implies that the molar ratio between ligand and substrate (CD and drug respectively) is not 1:1 [10].

In this case, it is very difficult to predict from these diagrams the real stoichiometry of CD-drug complex formation. Positive deviation has been described by Loftsson et al. [26] to be primarily associated with formation of water-soluble aggregates through non-inclusion complexation with a stoichiometry drug/CD from 1:2 to 1:3. Negative deviation from linearity is in most cases very difficult to describe stoichiometrically. Quoting Nicol at al. [27], studies on non-linear drug solubility based on the many-body interaction theory " $\mathrm{A}_{P}$ behavior is due to the overriding drug-CD interaction, whereas $\mathrm{A}_{\mathrm{N}}$ results from the overriding drug-induced weakening of $\mathrm{CD}-\mathrm{CD}$ interactions". If there is no increase 
or an increase followed by a drastic decrease of the substrate, solubility is measured with increasing concentration of $C D$, this generally indicates precipitation of the complex $C D$-drug. These diagrams are generally defined as $B$ types $\left(B_{S}\right.$ and $B_{I}$, Figure 3$)$ [13]. It has been reported that complexation efficiency of CDs might, in some cases, be negatively influenced by the presence of substituent groups anchored to the cavity entrance [17]. This phenomenon is attributed to steric hindrance that reduces the depth that the substrate molecule can reach in the CD cavity (Figure 5, [28]).

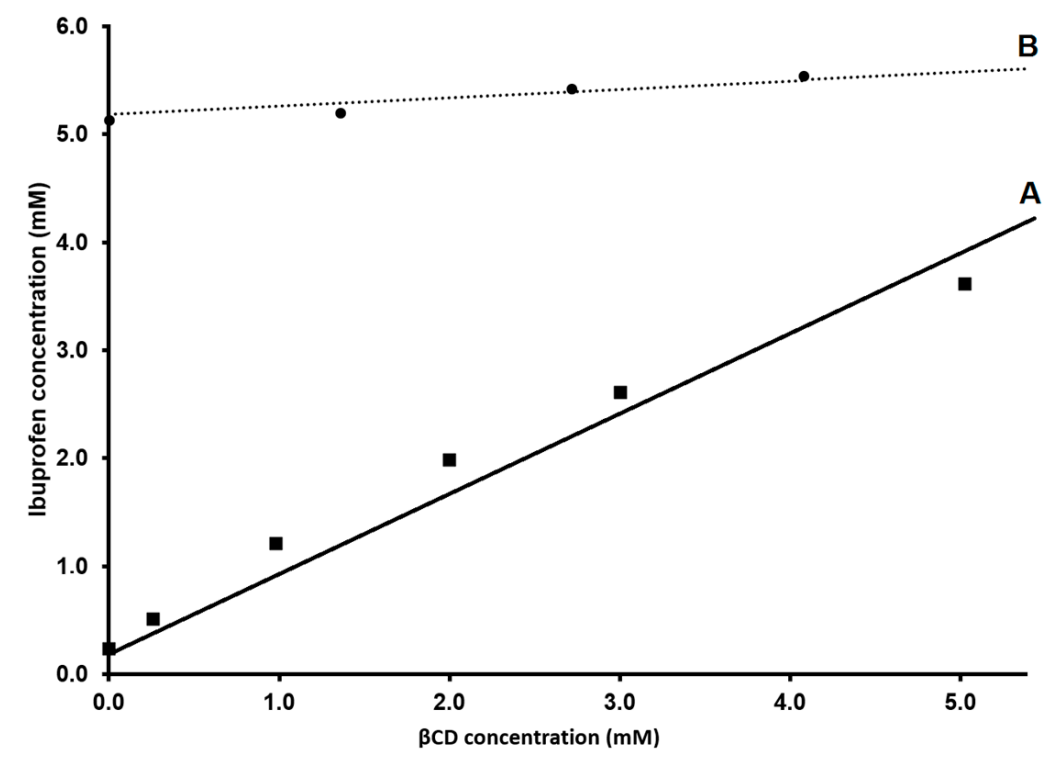

Figure 4. Phase-solubility profiles of IBU in the presence of $\beta C D$ obtained at $\mathrm{pH} 3.8(\mathbf{A})$ and at pH 7.4 (B). Personal communication data.
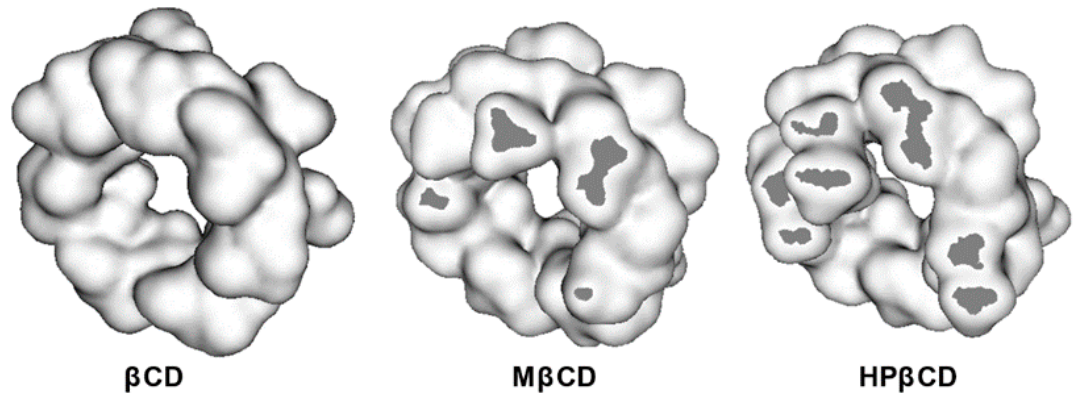

Figure 5. 3D representation (figure adapted from [28]) of native $\beta C D, M \beta C D$, and $H P \beta C D$. Dark grey sections represent the steric hindrance generated by the different type of substituent group.

\section{Food and Drugs Relevance of CDs}

The interest of pharmaceutical research and food industry has been mostly pointed to hepta-pyranose ring types and, to a lower extent, $\alpha$ - and $\gamma$ CDs. Figure 6 reports the number of search results obtained by typing the generic names of the most common CDs as keywords. This diagram clearly shows that $\beta C D$ (and its derivatives) are by far the most studied cyclic oligosaccharides, followed by $\alpha \mathrm{CD}$ and $\gamma \mathrm{CD}$. Figure 6 also shows that larger cyclodextrins are currently very poorly studied. 


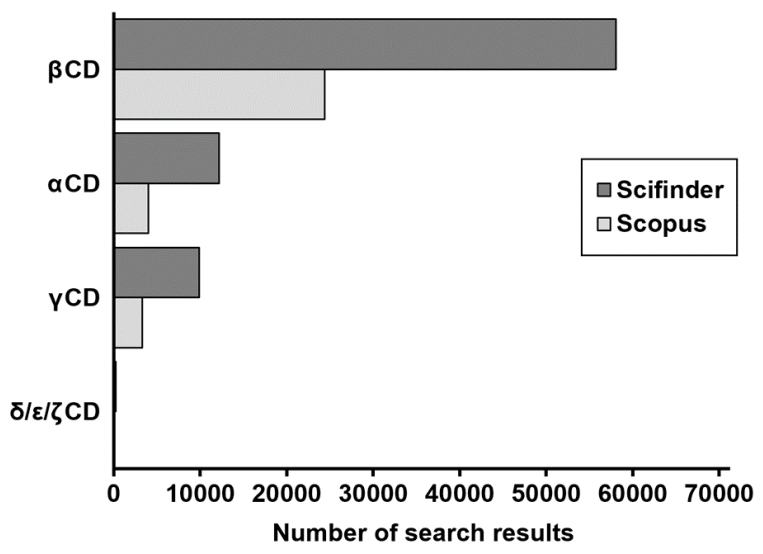

Figure 6. Number of search results obtained using as keyword the generic names of the most common CDs. Data collected from web search engines Scifinder (dark grey) and Scopus (light grey).

The ability of CDs, and especially the strong ability of $\beta C D$ s in forming stable inclusion complexes with poorly soluble and lipophilic moieties in aqueous environments, was immediately recognized to have big potentials in drug development and food industry. Cyclodextrins were first employed in the food industry in the 1970s, and from that time they have been mostly used as food additives for carrying food-related lipophiles (e.g., vitamins, aromas, and colorants) and for inhibiting light/heat mediated food degradation [29]. $\beta C D$ was found suitable as a cholesterol-reducing agent in food of animal origin such as mink and egg [30,31]. The first pharmaceutical patent related to CDs and pharmaceutical applicability as complexing agents is dated 1953 [32]. Cyclodextrins are employed in pharmaceutical products primarily to increase water solubility of poorly soluble APIs, in order to enhance their bioavailabilities. Pharmaceutical products containing CDs comprise nasal spray, oral solutions, solid dosage forms, ocular and dermal formulations, suppositories, and parenteral solutions [33]. Currently, more than 40 pharmaceutical products containing cyclodextrin are available in the market worldwide, and the vast majority of them utilize $\beta C D$ and its derivatives of higher water solubility such as $\mathrm{HP} \beta C D$, $M \beta C D$, and SBE $\beta C D$ [34]. Most of the $\beta C D$ are approved from the European Medical Agency (EMA) for all administration pathways besides parenteral administration where only $\mathrm{HP} \beta C D$ and $S B E \beta C D$ are approved [33]. $\mathrm{M} \beta C D$ application is limited to nasal and ocular administration due to side effects such as hemolysis. Even though $\mathrm{M} \beta \mathrm{CD}$ has thermodynamically favorable complexation potentials for phospholipids [35], it is assumed that the hemolytic effect is primarily related to cholesterol segregation and depletion from plasma membranes of erythrocytes [36,37]. It is largely unknown, but CDs were first employed as therapeutic agents almost 30 years ago. In fact, in 1987 Carpenter and co-workers administered $\mathrm{HP} \beta \mathrm{CD}$ to two siblings affected by an acute intoxication from retinoids (hypervitaminosis A). In this trial experiment, $\mathrm{HP} \beta C D$ proved to increase the urinary excretion of vitamin A, helping in the treatment of the acute symptoms of the intoxication [38].

The aim of the following sections is to present the reported interactions of $\beta C D$ s with some biological substrates and the consequent in vivo and in vitro effects induced by these interactions. These effects (poorly highlighted until now) might lead to the development of $\beta C D$ s as APIs.

\section{Interaction of Cyclodextrins with Biologically Relevant Substrates}

\subsection{Interaction with Cholesterol and Lipids}

The interaction of lipids and cholesterol with cyclodextrins has been extensively investigated in the last two decades. Loftsson and co-workers investigated the complexation reaction between cholesterol and different types of $\beta C D$ in aqueous dispersion by phase-solubility diagrams [26]. It was shown that cholesterol had the highest affinity for the most lipophilic $\beta C D$ (methylated one), but the lowest affinity for the very hydrophilic $\mathrm{HP} \beta C D$ and charged $\beta C D$ (i.e., SBE $\beta C D$ ). From the phase-solubility 
diagrams of uncharged cyclodextrins, they estimated the formation of 1:2 drug/cyclodextrin complexes. These findings were later confirmed from Nishijo and co-workers [39]. In their study, they characterized the aqueous complex between cholesterol and different sugar rings of different cavity sizes $(\alpha-, \beta-$, and $\gamma C D)$ using phase-solubility studies as well as NMR spectroscopy. Their results showed that only the methylated derivatives of $\beta C D(M \beta C D s)$ were able to complex and solubilize cholesterol in an aqueous environment, whereas native $\beta C D, \alpha C D$, and $\gamma C D$ cyclodextrin were not. More recent studies elucidated that native $\beta C D$ is also capable of complexing and solubilizing cholesterol, but the effect is not measurable through phase-solubility study at room temperature [40] because of the precipitation of the poorly soluble $\beta C D$-cholesterol conjugates. This observation was confirmed by molecular dynamic simulations studies [41]. Highly hydrophilic polymeric derivative of standard native $\beta C D$ (i.e., dextran derivative, $\beta C D$-dextran) showed comparable cholesterol-solubilization efficiency to $\mathrm{M} \beta \mathrm{CD}$ [42]. For the same polymers, it was proven by isothermal titration calorimetry that the complexation efficiency of the $\beta C D$ units was not negatively affected by the anchorage to the polymeric chain [43]. Recently, the ability of different types of $\beta C D$ to deplete cholesterol (and cholesteryl esters) from phospholipid bilayers has been proven. Stelzl and co-workers [42] showed that cholesterol depletion from giant unilamellar vesicles (GUV) composed of phosphatidylcholine (PC) and cholesterol was a favorable process that spontaneously took place when the lipid bilayers were exposed to different types of $\beta C D$ (primarily $M \beta C D, \beta C D$-dextran and, to a smaller extent, $\mathrm{HP} \beta C D$ ) in a water environment. A similar study conducted by Litz and co-workers showed by fluorescence spectroscopy that cholesterol removal from GUVs was extremely fast (in the order of milliseconds), and it produced the formation of extended holes in the lipid bilayers (in vesicles composed by both saturated and unsaturated phospholipids) [44]. $\mathrm{M} \beta C D$ was found to have a strong and thermodynamically favorable inclusion affinity also for the phospholipids composing the vesicle bilayer (1-palmitoyl-2-oleoyl-sn-glycero-3-phosphocholine) [35]. Interestingly, Ao and co-workers [45] recently have shown that hydrophobic derivatives of $\beta C D$ s (i.e., $M \beta C D$ ) are capable of disassembling low-density lipoprotein aggregates (LDL) by lipids (both phospholipids and cholesterol) segregation and they are significantly reducing the oxidation tendency of LDL (widely accepted as the key trigger of atherosclerosis).

\subsection{Interaction with Proteins}

Cyclodextrins have been found to be capable of interacting not only with lipophilic moieties but also with hydrophilic biological macromolecules such as proteins, effecting their stability and aggregation tendency [46]. Differential scanning calorimetry (DSC) of a range of proteins has shown that $\alpha$ - and $\beta C D$ s can reduce the mean unfolding temperature of some biologically relevant proteins (e.g., lysozyme, ribonuclease A, ubiquitin, and yeast phosphoglycerate kinase). It has been suggested that this phenomenon is related to the inclusion of aromatic portions of some amino acids (e.g., tryptophan) from CDs, effecting protein stability [47]. The spontaneous inclusion tendency of $\beta C D$ s of amino acids containing aromatic groups was later confirmed by a combined NMR and molecular docking approach [48]. Other studies showed that both $M \beta C D$ and $H P \beta C D$ were capable of forming spontaneous complexes with a portion of insulin, inducing a stabilizing/protecting effect in different aqueous environments and temperatures [49,50]. This stabilization effect also prevented aggregation of insulin molecules in solution. Another very interesting interaction that has been described is the interaction between $\beta C D$ s and $\beta$-amyloid peptide [51]. B-amyloid is the major constituent of the plaques forming in the human brain that induce Alzheimer's disease (AD). It has been shown that $\beta C D$ s can form inclusion complexes with portions of the peptide (where tyrosine and phenylalanine amino acids are located) [52]. This interaction sensibly reduces the aggregation tendency of this peptide in aqueous solution.

All these spontaneous interactions between CDs and biologically relevant substrates induce evident effects when cyclodextrin is applied in vitro or administered in vivo. 


\section{Effect of Cyclodextrin In Vitro}

Cholesterol is an essential component of plasma cell membranes. It is fundamental in keeping barrier integrity and its involvement in the growth and proliferation of cells has been described. In 1982, Irie and co-workers reported a lytic and shape-changing effect induced on human erythrocytes by some types of $C D$ derivatives and in particular HP $\beta C D$ s [53]. They observed a change in surface tension in the plasma membrane and they suggested that this phenomenon was due to segregation of important components of cell barriers (lipids and cholesterol in particular). In 1994, Learoy-Lechat and co-workers identified that, when eukaryotic cell lines (such as erythrocytes and murine leukemic cells P388) were incubated with significant amount of different $\alpha_{-}, \beta-$, and $\gamma \mathrm{CD}$ (unmodified and hydroxypropylated), their viability was compromised [54]. The in vitro cytotoxicity of CDs was ranked as $\beta C D>\alpha C D>\gamma C D$ (the same ranking was found for the hydroxypropylated derivatives). In accordance with Irie and co-workers, they also suggested that segregation of important components of cell membranes from CDs (in particular cholesterol) was the key factor in triggering hemolysis. More recently, an effect of CDs on plasma fibrinogen and a consequent effect on coagulation has also been described [55].

Another study performed by Kiss and co-workers [36] (focused primarily on both neutral and ionic derivatives of $\beta C D$ ) demonstrated a solid correlation between $\beta C D$ s cytotoxicity and cholesterol segregation ability. In this regard, it has been shown that the depletion of cholesterol from cell membranes can lead to spontaneous activation of apoptotic/necrotic mechanisms [56-59]. However, it is still unclear which cellular mechanism promotes cell death after cholesterol depletion. One possible mechanism might be related to the perturbation of cell raft domains and the consequent alteration of the cascade of intramolecular signals regulated by them. In fact, the lipid raft domains of plasma membranes control several membrane receptors and regulate a number of intracellular signaling pathways [60]. Membrane lipid rafts have been implicated in the regulation of malignant cell proliferation, differentiation, apoptosis, and migration [61,62], suggesting that the alteration of these domains might lead to inhibition of metastatic cells growth/migration, also inducing cell death [63]. As mentioned earlier, hepta-sucrose rings showed ability in interaction with peptides and proteins. A recent study from Ren and co-workers [64] has shown that HP $\beta C D$ owns strong inhibitory effect on the aggregation of amyloid- $\beta$ peptides. They also have shown that administration of HP $\beta C D$ on compromised neuroblastoma cells (i.e., previously exposed to $\beta$-amyloid peptide) significantly increases cell viability.

\section{Potentials of Cyclodextrins in Therapy: In Vivo and in Human Evidence}

\subsection{Cyclodextrin Potentials on Atherosclerosis and Dyslipidemia Treatment}

One of the predominant pharmacological effects that is reported in the literature for $\beta C D s$ derivatives is their positive pharmacological activity on the cardiovascular system. In 1992. Irie and co-workers administered intravenous (IV) HP $\beta C D$ to hyperlipidemic rabbit. They demonstrated a decrease in blood cholesterol levels after a single administration [53]. Sustained parenteral administration of $\mathrm{HP} \beta C D$ in animals increased cholesterol concentration in urines, inducing a positive effect on atherosclerotic plaques. In their 1995 study, Favier and co-workers [65] orally administered to male Wistar rats daily doses of $\beta C D$ through animals' regular food. Amazingly, they demonstrated that $\beta C D$ acted as a very efficient hypocholesterolemic agent. They verified that the blood cholesterol content, as well as the concentrations of low density lipoprotein protein (LDL) and very low density lipoprotein (VLDL), were significantly reduced when $\beta C D$ were administered through the food. Whereas concentration of high density lipoprotein (HDL) was less effected. A significant reduction in lipoprotein triglycerides content was also demonstrated, but predominantly when $\beta C D$ were administered through a low-fat dietary regime.

Rivers and co-worker focused their attention on hypoxia and ischemia, demonstrating that the administration of $\mathrm{HP} \beta C D$ to rats after $30 \mathrm{~min}$ from the appearance of hypoxia/ischemia symptoms 
significantly reduced brain injuries [66]. The authors proposed HP $\beta C D$ as a possible new treatment of cerebral ischemic injury. More recently, it has been shown that intraperitoneal administration of aqueous infusion of KLEPTOSE ${ }^{\circledR}$ CRYSMEB (commercial name of M $\beta C D$ from Rochètte Freres, Lestrem, France) were able to efficiently reduce atherosclerosis in $\mathrm{ApoE}^{-/-}$male mice (class of mice often employed as in vivo models for atherosclerosis). Similar results were obtained by Zimmer and co-workers [67] on the same animal model but employing the more hydrophilic and FDA/EMA approved HP $\beta C D$. Both studies agreed that the mechanism by which $\beta C D$ derivatives develop regression in atherosclerosis was a combination of alteration of lipid profile (i.e., hypocholesterolemic effect) and by influencing the inflammatory response that triggers atherosclerotic plaque formation (i.e., interaction with macrophages and lymphocytes). Zimmer and co-workers actually proposed $\mathrm{HP} \beta C D$ as a new treatment for atherosclerosis.

\subsection{Cyclodextrins Potentials in Chemotherapy}

As described previously, $\beta C D$ and its derivatives of higher water solubility (i.e., $M \beta C D$ and $\mathrm{HP} \beta C D)$ have shown interesting cytostatic/cytotoxic activity cholesterol-depletion mediated on different cell lines. However, just a handful of studies have been conducted to verify the potential of $\beta C D$ s as APIs in chemotherapy. In 1998, Grosse and co-workers [68] demonstrated that intraperitoneal (IP) injections of aqueous solution of $\mathrm{M} \beta C D$ significantly inhibited the growth of human solid tumors implanted on mice (breast cancer and ovarian carcinoma cell lines). The antiproliferative effect of $\mathrm{M} \beta C D$ was comparable to the one measured for doxorubicin. Intratumoral (IT) injection of $M \beta C D$ aqueous solutions resulted in an even higher antiproliferative effect [58]. More recently, Mohammed and co-workers proved that administration of tamoxifen in combination with M $\beta C D$ significantly diminished (approx. 75\% in normal diet fed animals) the size and weight of solid tumors in mice [69]. They also found out that, when animals were feed with a cholesterol rich dietary regime, no significant reduction in the size of the solid tumor was measurable when $\mathrm{M} \beta C D$ and/or tamoxifen where administered. This fact clearly indicates that cholesterol plays a fundamental role in tumor growth and that $\mathrm{M} \beta \mathrm{CD}$ activity is almost certainly related to cholesterol depletion from the organism. Onodera and co-workers showed that folate-conjugated $\mathrm{M} \beta C D$ possessed an even higher antiproliferative activity on solid tumors (IT and IV injections) [70] as well as on melanoma (subcutaneous administration, SC) [58] with negligible side effects. The higher activity of these folate derivatives could be related to the higher number of folate receptors expressed by cancer cells in comparison to healthy cells (i.e., selectivity of action). Yokoo and coworkers showed that HPBCD also possessed antitumor action, demonstrating cell growth inhibition and apoptosis in leukemic cells in vitro and in vivo [71].

\subsection{Cyclodextrin Potentials in the Treatment of Degenerative Brain Disease}

CDs have been investigated as possible treatment for Niemann-Pick type C (NPC) disease. This syndrome is characterized by accumulation of esterified cholesterol and other lipids in cells, predominantly in liver and central nervous systems. This uncontrolled accumulation causes irreversible brain and liver damage that ultimately leads to death. Currently, no efficient medicine is available for the treatment of NPC. IV administration of HP $\beta C D$ to symptomatic $\mathrm{Npc}^{-/}$mice (standard animal model for NPC) proved to sensibly delay the onset of neurological symptoms in the animals [72]. Later study showed that SC and IP administration of HP $\beta$ CD to NPC diseased mice could reduce neuronal cholesterol accumulation [73]. Interestingly, the life span of animals was prolonged to the same extent as for miglustat administration (the only API approved for NPC treatment). Detailed histological investigations also revealed a clear reduction in cholesterol accumulation in the most sensitive organs of $\mathrm{Npc}^{-/-}$mice (liver, spleen, and kidneys) after weekly administration of $\mathrm{HP} \beta C D$ (SC injections) [74]. A similar study conducted by Tanaka et al. identified a significant increase in life span of $\mathrm{Npc1}^{-/-}$of mice after daily SC administration of HP $\beta C D$ [75]. In recent years, several investigative new drug application documents for cyclodextrin treatment for Niemann Pick Type C disease were filed [76] (and approved by FDA). Intravenous administration of HP $\beta$ CD in human 
patients proved to be not so effective due to the moderate permeability of the pyranose derivatives through the blood brain barrier (BBB) [77]. In this regard, intrathecal infusion of $\beta C D$ s resulted in a much more efficient administration pathway and, nowadays, several pharmaceutical trials employing $\mathrm{HP} \beta C D$ for NPC on humans are currently underway in several countries [78].

Another extremely severe neurological disorder that is not treatable by current medicines is Alzheimer Disease (AD). Yao and co-workers [79] proved that weekly subcutaneous injection of HP $\beta C D$ in mice model for AD (TG19959) could significantly improve memory deficits and reduce $\beta$-amyloid peptide neuronal deposition. It was suggested that the reduction in $\beta$-amyloid aggregation/deposition in the neurons could be related to alteration in cholesterol metabolism. Subsequent studies have suggested that $\mathrm{HP} \beta C D$ probably interacts with $\beta$-amyloid peptide, reducing its aggregation and deposition tendency [64]. Even though the mechanism of action is not completely understood yet, $\mathrm{HP} \beta C D$ shows potential for the treatment of $\mathrm{AD}$.

A summary of the cyclodextrins that have been investigated as possible active pharmaceutical ingredients in vivo (and in humans) is reported in Table 2.

Table 2. Types of cyclodextrins that have been investigated as possible active pharmaceutical ingredients in vivo (and in humans *).

\begin{tabular}{|c|c|c|c|c|c|}
\hline Cyclodextrin Type & Hypervitaminosis A & Dyslipidemia and Atherosclerosis & Chemotherapy & NPC & AD \\
\hline$\beta C D$ & & $\mathrm{x}$ & & & \\
\hline $\mathrm{M} \beta C D$ & & $\mathrm{X}$ & $\mathrm{X}$ & & \\
\hline $\mathrm{HP} \beta \mathrm{CD}$ & $X^{*}$ & $x$ & $x$ & $X^{*}$ & $x$ \\
\hline
\end{tabular}

\section{Conclusions}

In the last three decades, cyclodextrin derivatives have shown tremendous potential for the treatment for different diseases where available medicines in the market are failing to provide proper treatment. Despite the promising results achieved in the last years, the interest of the pharmaceutical community and industries in developing CDs as active pharmaceutical ingredients remain regrettably low. As for the treatment of NPC, it is desirable that, cyclodextrins that are already approved from American and European medical agencies could be promptly used in human trials to verify their real potential as therapeutic agents. Moreover, the development of new CD types (e.g., polymeric cyclodextrins) is to be encouraged, because it might lead to the discovery of the ultimate cure for diseases such as atherosclerosis, cancer, and degenerative brain diseases that remain, at present, still of poor treatability and considerable lethality.

Acknowledgments: The author would like to thank Mathilde Goulet and Lotte Brunbjerg for acquiring the data presented in this review as personal communication.

Conflicts of Interest: The authors report no conflict of interest.

\section{Abbreviations}

The following abbreviations are used in this manuscript:

$\begin{array}{ll}\text { API } & \text { active pharmaceutical ingredient } \\ \text { CD } & \text { cyclodextrin } \\ \alpha C D & \text { alpha-cyclodextrin } \\ \beta C D & \text { beta-cyclodextrin } \\ \text { HP } \beta C D & \text { hydroxypropyl-beta-cyclodextrin } \\ \text { M } \beta C D & \text { methyl-beta-cyclodextrin } \\ \text { SBE } \beta C D & \text { sulfobutyl-ether-beta-cyclodextrin } \\ \gamma C D & \text { gamma-cyclodextrin } \\ \text { IP } & \text { intra peritoneal } \\ \text { IV } & \text { intra venous } \\ \text { SC } & \text { subcutaneous } \\ \text { NPC } & \text { Niemann-Pick type C disease } \\ \text { AD } & \text { Alzheimer's disease }\end{array}$




\section{References}

1. Martínez Mora, M.M.; Hernández Sánchez, K.; Villalonga Santana, R.; Pérez Rojas, A.; Ramírez, H.L.; Torres-Labandeira, J.J. Partial purification and properties of cyclodextrin glycosiltransferase (CGTase) from alkalophilic Bacillus species. SpringerPlus 2012, 1, 1-6.

2. Crini, G. Review: A history of cyclodextrins. Chem. Rev. 2014, 114, 10940-10975. [CrossRef] [PubMed]

3. French, D.; Rundle, R.E. The molecular weights of the Shardinger Alpha and Beta Dextrins. J. Am. Chem. Soc. 1942, 64, 1651-1653. [CrossRef]

4. Cramer, F. Einshluss-Verbindungen; Springer: Berlin, Germany, 1954.

5. Pulley, A.O.; French, D. Studies on the Schardinger Dextrins. Biochem. Biophys. Res. Commun. 1961, 5, 11-15. [CrossRef]

6. Larsen, K.L. Large cyclodextrins. J. Incl. Phenom. Macrocycl. Chem. 2002, 43, 1-13. [CrossRef]

7. Jozwiakowski, M.J.; Connors, K.A. Aqueous solubility behavior of three cyclodextrins. Carbohydr. Res. 1985, 143, 51-59. [CrossRef]

8. Dunchene, D. Cyclodextrins and their inclusion complexes. In Cyclodextrins in Pharmaceutics, Cosmetics, and Biomedicine: Current and Future Industrial Applications; Bilensoy, E., Ed.; John Wiley \& Sons, Inc.: Hoboken, NJ, USA, 2011; p. 15.

9. Connors, K.A. The stability of cyclodextrin complexes in solution. Chem. Rev. 1997, 97, 1325-1357. [CrossRef] [PubMed]

10. Uekama, K.; Hirayama, F.; Irie, T. Cyclodextrin drug carrier systems. Chem. Rev. 1998, 98, $2045-2076$. [CrossRef] [PubMed]

11. Nielsen, T.T.; Wintgens, V.; Amiel, C.; Wimmer, R.; Larsen, K.L. Facile synthesis of $\beta$-cyclodextrin-dextran polymers by "Click" chemistry. Biomacromolecules 2010, 11, 1710-1715. [CrossRef] [PubMed]

12. Nielsen, T.T.; Wintgens, V.; Larsen, K.L.; Amiel, C. Synthesis and characterization of poly(ethylene glycol) based $\beta$-cyclodextrin polymers. J. Incl. Phenom. Macrocycl. Chem. 2009, 65, 341-348. [CrossRef]

13. Tong, W.; Wen, H. Applications of complexation in the formulation of insoluble compounds. In Water-Insoluble Drug Formulations, 2nd ed.; Liu, R., Ed.; Taylor \& Frencis Group: Boca Raton, FL, USA, 2008.

14. Connors, K.A. Population Characteristics of Cylcodextrin Complex Stabilities in Aqueous Solutions. J. Pharm. Sci. 1995, 85, 843-848. [CrossRef]

15. Perlovich, G.L.; Skar, M.; Bauer-Brandl, A. Driving forces and the influence of the buffer composition on the complexation reaction between ibuprofen and HPBCD. Eur. J. Pharm. Sci. 2003, 20, 197-200. [CrossRef]

16. Takahashi, A.I.; Veiga, F.J.B.; Ferraz, H.G. A literature review of cyclodextrin inclusion complexes characterization-Part III: Differential scanning calorimetry and thermogravimetry. Int. J. Pharm. Sci. Rev. Res. 2012, 12, 16-20.

17. Di Cagno, M.; Stein, P.C.; Skalko-Basnet, N.; Brandl, M.; Bauer-Brandl, A. Solubilization of ibuprofen with beta-cyclodextrin derivatives: Energetic and structural studies. J. Pharm. Biomed. Anal. 2011, 55, 446-451. [CrossRef] [PubMed]

18. Takahashi, A.I.; Veiga, F.J.B.; Ferraz, H.G. A literature review of cyclodextrin inclusion complexes characterization-Part II: X-ray diffraction, infrared spectroscopy and nuclear magnetic resonance. Int. J. Pharm. Sci. Rev. Res. 2012, 12, 8-15.

19. Uyar, T.; Hunt, M.A.; Gracz, H.S.; Tonelli, A.E. Crystalline cyclodextrin inclusion compounds formed with aromatic guests: Guest-dependent stoichiometries and hydration-sensitive crystal structures. Cryst. Growth Des. 2006, 6, 1113-1119. [CrossRef]

20. Lichtenthaler, F.W.; Immel, S. Molecular modeling of saccharides. Part 9. On the hydrophobic characteristics of cyclodextrins: Computer-aided visualization of molecular lipophilicity patterns. Liebigs Ann. 1996, 1, 27-37.

21. Brewster, M.E.; Loftsson, T. Cyclodextrins as pharmaceutical solubilizers. Adv. Drug Deliv. Rev. 2007, 59, 645-666. [CrossRef] [PubMed]

22. Higuchi, T.; Connors, K.A. Phase-solubility techniques. In Advances in Analytical Chemistry and Instrumentation; Reilley, C.N., Ed.; John Wiley \& Sons, Inc.: Hoboken, NJ, USA, 1965; Volume 4, pp. 117-212.

23. Loftsson, T.; Hreinsdottir, D.; Masson, M. Evaluation of cyclodextrin solubilization of drugs. Int. J. Pharm. 2005, 302, 18-28. [CrossRef] [PubMed] 
24. Xing, S.; Zhang, Q.; Zhang, C.; Zhao, Q.; Ai, H.; Sun, D. Isothermal Titration Calorimetry and Theoretical Studies on Host-guest Interaction of Ibuprofen with $\alpha-, \beta$ - and $\gamma$-Cyclodextrin. J. Sol. Chem. 2009, 38, 531-543. [CrossRef]

25. Oh, I.; Lee, M.; Lee, Y.; Shin, S.; Park, I. Spectroscopic characterization of ibuprofen/2-hydroxypropyl - $\beta$-cyclodextrin inclusion complex. Int. J. Pharm. 1998, 175, 215-223. [CrossRef]

26. Loftsson, T.; Magnúsdóttir, A.; Másson, M.; Sigurjónsdóttir, F. Self-association and cyclodextrin solubilization of drugs. J. Pharm. Sci. 2002, 91, 2307-2316. [CrossRef] [PubMed]

27. Nicol, T.W.; Matubayasi, N.; Shimizu, S. Origin of non-linearity in phase solubility: Solubilisation by cyclodextrin beyond stoichiometric complexation. Phys. Chem. Chem. Phys. 2016, 18, 15205-15217. [CrossRef] [PubMed]

28. Di Cagno, M.P. Overcoming Poor Solubility and Instability of New Anticancer Drug Candidates; Design of Water-Based Formulations for In Vitro Studies. Ph.D. Thesis, University of Southern Denmark, Odense, Denmark, April 2012.

29. Fenyvesi, E.; Vikmon, M.; Szente, L. Cyclodextrins in Food Technology and Human Nutrition: Benefits and Limitations. Crit. Rev. Food Sci. Nutr. 2016, 56, 1981-2004. [CrossRef] [PubMed]

30. Smith, D.M.; Awad, A.C.; Bennink, M.R.; Gill, J.L. Cholesterol reduction in liquid egg yolk using $\beta$-cyclodextrin. J. Food Sci. 1995, 69, 691-694. [CrossRef]

31. Awad, A.C.; Bennink, M.R.; Smith, D.M. Composition and functional properties of cholesterol reduced egg yolk. Poult. Sci. 1997, 76, 649-653. [CrossRef] [PubMed]

32. Loftsson, T.; Duchene, D. Cyclodextrins and their pharmaceutical applications. Int. J. Pharm. 2007, 329, 1-11. [CrossRef] [PubMed]

33. EMA Background Review for Cyclodextrins Used as Excipients. Available online: http://www.ema.europa. eu/docs/en_GB/document_library/Report/2014/12/WC500177936.pdf (accessed on 10 November 2016).

34. Cyclolab. Approved Pharmaceutical Products Containing Cyclodextrins. Available online: http:/ / www.pharmacompass.com/pAssets/pdf/party/Zibo-Qianhui-Biological-Technology-Co-Ltdregulatory-1435833292.pdf (accessed on 20 November 2016).

35. Anderson, T.G.; Tan, A.; Ganz, P.; Seelig, J. Calorimetric measurement of phospholipid interaction with methyl- $\beta$-cyclodextrin. Biochemistry 2004, 43, 2251-2261. [CrossRef] [PubMed]

36. Kiss, T.; Fenyvesi, F.; Bacskay, I.; Varadi, J.; Fenyvesi, E.; Ivanyi, R.; Szente, L.; Tosaki, A.; Vecsernyes, M. Evaluation of the cytotoxicity of beta-cyclodextrin derivatives: Evidence for the role of cholesterol extraction. Eur. J. Pharm. Sci. 2010, 40, 376-380. [CrossRef] [PubMed]

37. Irie, T.; Otagiri, M.; Sunada, M.; Uekama, K.; Ohtani, Y.; Yamada, Y.; Sugiyama, Y. Cyclodextrins-induced hemolysis and shape changes of human erythrocytes in vitro. J. Pharm. Dyn. 1982, 4, 741-744. [CrossRef]

38. Carpenter, T.O.; Pettifor, J.M.; Russell, R.M.; Pitha, J.; Mobarhan, S.; Ossip, M.S.; Wainer, S.; Anast, C.S. Severe hypervitaminosis A in siblings: Evidence of variable tolerance to retinol intake. J. Pediatr. 1987, 111, 507-512. [CrossRef]

39. Nishijo, J.; Moruyama, S.; Shiota, S. Interactions of cholesterol with cyclodextrins in acqueous solution. Chem. Pharm. Bull. 2003, 51, 1253-1257. [CrossRef] [PubMed]

40. Dos Santos, C.; Buera, M.P.; Mazzobre, M.F. Phase solubility studies and stability of cholesterol/beta-cyclodextrin inclusion complexes. J. Sci. Food Agric. 2011, 91, 2551-2557. [CrossRef] [PubMed]

41. Lopez, C.A.; de Vries, A.H.; Marrink, S.J. Molecular mechanism of cyclodextrin mediated cholesterol extraction. PLoS Comput. Biol. 2011, 7, e1002020. [CrossRef] [PubMed]

42. Stelzl, D.; Nielsen, T.T.; Hansen, T.; di Cagno, M. Beta-CD-dextran polymer for efficient sequestration of cholesterol from phospholipid bilayers: Mechanistic and safe-toxicity investigations. Int. J. Pharm. 2015, 496, 896-902. [CrossRef] [PubMed]

43. Di Cagno, M.; Terndrup Nielsen, T.; Lambertsen Larsen, K.; Kuntsche, J.; Bauer-Brandl, A. $\beta$-Cyclodextrin-dextran polymers for the solubilization of poorly soluble drugs. Int. J. Pharm. 2014, 468, 258-263. [CrossRef] [PubMed]

44. Litz, J.P.; Thakkar, N.; Portet, T.; Keller, S.L. Depletion with cyclodextrin reveals two populations of cholesterol in model lipid membranes. Biophys. J. 2016, 110, 635-645. [CrossRef] [PubMed]

45. Ao, M.; Gan, C.; Shao, W.; Zhou, X.; Chen, Y. Effects of cyclodextrins on the structure of LDL and its susceptibility to copper-induced oxidation. Eur. J. Pharm. Sci. 2016, 91, 183-189. [CrossRef] [PubMed] 
46. Cooper, A. Effect of cyclodextrins on the thermal stability of globular protein. J. Am. Chem. Soc. 1992, 114, 9208-9209. [CrossRef]

47. Niccoli, M.; Oliva, R.; Castronuovo, G. Cyclodextrin-protein interaction as inhibiting factor against aggregation. J. Therm. Anal. Calorim. 2016. [CrossRef]

48. Caso, J.V.; Russo, L.; Palmieri, M.; Malgieri, G.; Galdiero, S.; Falanga, A.; Isernia, C.; Iacovino, R. Investigating the inclusion properties of aromatic amino acids complexing beta-cyclodextrins in model peptides. Amino Acids 2015, 47, 2215-2227. [CrossRef] [PubMed]

49. Dotsikas, Y.; Loukas, Y.L. Kinetic degradation study of insulin complexed with methyl-beta cyclodextrin. Confirmation of complexation with electrospray mass spectrometry and ${ }^{1} \mathrm{H}-\mathrm{NMR}$. J. Pharm. Biomed. Anal. 2002, 29, 487-494. [CrossRef]

50. Zhang, L.; Zhu, W.; Song, L.; Wang, Y.; Jiang, H.; Xian, S.; Ren, Y. Effects of hydroxylpropyl-beta-cyclodextrin on in vitro insulin stability. Int. J. Mol. Sci. 2009, 10, 2031-2040. [CrossRef] [PubMed]

51. Camilleri, P.; Haskins, N.J.; Howlett, D.R. $\beta$-Cyclodextrin interactions with the Alzheimer $\beta$-amyloid-4A peptide. FEBS Lett. 1994, 341, 256-258. [CrossRef]

52. Danielsson, J.; Jarvet, J.; Damberg, P.; Gräslund, A. Two-site binding of $\beta$-cyclodextrin to the Alzheimer A $\beta(1-40)$ peptide measured with combined PFG-NMR diffusion and induced chemical shifts. Biochemistry 2004, 43, 6261-6269. [CrossRef] [PubMed]

53. Irie, T.; Fukunaga, K.; Garwood, M.K.; Carpenter, T.O.; Pitha, J.; Pitha, J. Hydroxypropylcyclodextrins in parenteral use. II: Transport and disposition of lipids in rabbit and effects on human. J. Pharm. Sci. 1992, 81, 524-528. [CrossRef] [PubMed]

54. Leroy-Lechat, F.; Wouessidjewe, D.; Andreux, J.; Puisiex, F.; Duchêne, D. Evaluation of the cytotoxicity of cyclodextrins and hydroxypropylated derivatives. Int. J. Pharm. 1994, 101, 97-103. [CrossRef]

55. Fu, Y.; Wang, X.; Zhang, Y.; Liu, Z.; Xue, W. Effect of cyclodextrins on the structure and functions of blood components in vitro. J. Bioact. Compat. Polym. 2015, 30, 541-554. [CrossRef]

56. Gniadecki, R. Depletion of membrane cholesterol causes ligand-independent activation of Fas and apoptosis. Biochem. Biophys. Res. Commun. 2004, 320, 165-169. [CrossRef] [PubMed]

57. Li, Y.C.; Park, M.J.; Ye, S.K.; Kim, C.W.; Kim, Y.N. Elevated levels of cholesterol-rich lipid rafts in cancer cells are correlated with apoptosis sensitivity induced by cholesterol-depleting agents. Am. J. Pathol. 2006, 168, 1107-1118. [CrossRef] [PubMed]

58. Onodera, R.; Motoyama, K.; Okamatsu, A.; Higashi, T.; Kariya, R.; Okada, S.; Arima, H. Involvement of cholesterol depletion from lipid rafts in apoptosis induced by methyl-beta-cyclodextrin. Int. J. Pharm. 2013, 452, 116-123. [CrossRef] [PubMed]

59. Yamaguchi, R.; Perkins, G.; Hirota, K. Targeting cholesterol with beta-cyclodextrin sensitizes cancer cells for apoptosis. FEBS Lett. 2015, 589, 4097-4105. [CrossRef] [PubMed]

60. Diaz-Rohrer, B.; Levental, K.R.; Levental, I. Rafting through traffic: Membrane domains in cellular logistics. Biochim. Biophys. Acta 2014, 1838, 3003-3013. [CrossRef] [PubMed]

61. Murai, T. The role of lipid rafts in cancer cell adhesion and migration. Int. J. Cell Biol. 2012, 2012, 763283. [CrossRef] [PubMed]

62. Codini, M.; Cataldi, S.; Lazzarini, A.; Tasegian, A.; Caccarini, M.R.; Floridi, A.; Lazzarini, R.; Ambesi-Impiombato, F.S.; Curcio, F.; Beccari, T.; et al. Why high cholesterol levels help hematological malignancies: Role of nuclear lipid microdomains. Lipids Health Dis. 2016, 15, 4. [CrossRef] [PubMed]

63. Hryniewicz-Jankowska, A.; Augoff, K.; Biernatowska, A.; Podkalicka, J.; Sikorski, A.F. Membrane rafts as a novel target in cancer therapy. Biochim. Biophys. Acta 2014, 1845, 155-165. [CrossRef] [PubMed]

64. Ren, B.; Jiang, B.; Hu, R.; Zhang, M.; Chen, H.; Ma, J.; Sun, Y.; Jia, L.; Zheng, J. HP-beta-cyclodextrin as an inhibitor of amyloid-beta aggregation and toxicity. Phys. Chem. Chem. Phys. 2016, 18, 20476-20485. [CrossRef] [PubMed]

65. Favier, M.L.; Rémésy, C.; Moundras, C.; Demigné, C. Effect of cyclodextrin on plasma lipids and cholesterol metabolism in the Rat. Metabolism 1995, 44, 200-206. [CrossRef]

66. Rivers, J.R.; Maggo, S.D.; Ashton, J.C. Neuroprotective effect of hydroxypropyl-beta-cyclodextrin in hypoxia-ischemia. Neuroreport 2012, 23, 134-138. [CrossRef] [PubMed]

67. Zimmer, S.; Grebe, A.; Bakke, S.S.; Bode, N.; Halvorsen, B.; Ulas, T.; Skjelland, M.; De Nardo, D.; Labzin, L.I.; Kerksiek, A.; et al. Cyclodextrin promotes atherosclerosis regression via macrophage reprogramming. Sci. Transl. Med. 2016, 8. [CrossRef] [PubMed] 
68. Grosse, P.Y.; Bassolle, F.; Pinguet, F. Antiproliferative effect of methyl- $\beta$-cyclodextrin in vitro and in human tumor xenografted athymic nude mice. Br. J. Cancer 1998, 78, 1165-1169. [CrossRef] [PubMed]

69. Mohammad, N.; Malvi, P.; Meena, A.S.; Vikram Singh, S.V.; Chaube, B.; Vannuruswamy, G.; Kulkarni, M.J.; Kumar Bhat, K.K. Cholesterol depletion by methyl- $\beta$-cyclodextrin augments tamoxifen induced cell death by enhancing its uptake in melanoma. Mol. Cancer 2014, 13, 204. [CrossRef] [PubMed]

70. Onodera, R.; Motoyama, K.; Okamatsu, A.; Higashi, T.; Arima, H. Potential use of folate-appended methyl-beta-cyclodextrin as an anticancer agent. Sci. Rep. 2013, 3. [CrossRef] [PubMed]

71. Yokoo, M.; Kubota, Y.; Motoyama, K.; Higashi, T.; Taniyoshi, M.; Tokumaru, H.; Nishiyama, R.; Tabe, Y.; Mochinaga, S.; Sato, A.; et al. 2-Hydroxypropyl-beta-Cyclodextrin acts as a novel anticancer agent. PLoS ONE 2015, 4. [CrossRef]

72. Camargo, F.; Erickson, R.P.; Garver, W.S.; Hossain, G.S.; Carbone, P.N.; Heidenreich, R.A.; Blanchard, J. Cyclodextrins in the treatment of a mouse model of Niemann-Pick C disease. Life Sci. 2001, 70, 131-142. [CrossRef]

73. Davidson, C.D.; Ali, N.F.; Micsenyi, M.C.; Stephney, G.; Renault, S.; Dobrenis, K.; Ory, D.S.; Vanier, M.T.; Walkley, S.U. Chronic cyclodextrin treatment of murine Niemann-Pick C disease ameliorates neuronal cholesterol and glycosphingolipid storage and disease progression. PLoS ONE 2009, 4, e6951. [CrossRef] [PubMed]

74. Lopez, A.M.; Terpack, S.J.; Posey, K.S.; Liu, B.; Ramirez, C.M.; Turley, S.D. Systemic administration of 2-hydroxypropyl-beta-cyclodextrin to symptomatic Npc1-deficient mice slows cholesterol sequestration in the major organs and improves liver function. Clin. Exp. Pharmacol. Physiol. 2014, 41, 780-787. [CrossRef] [PubMed]

75. Tanaka, Y.; Yamada, Y.; Ishitsuka, Y.; Matsuo, M.; Shiraishi, K.; Wada, K.; Uchio, Y.; Kondo, Y.; Takeo, T.; Nakagata, N.; et al. Efficacy of 2-hydroxypropyl- $\beta$-cyclodextrin in Niemann-Pick disease type C model mice and its pharmacokinetic analysis in a patient with the disease. Biol. Pharm. Bull. 2015, 38, 844-851. [CrossRef] [PubMed]

76. Hastings, C. Request for Intratecal Delivery of HPBCD for Niemann Pick Type C Patients. Available online: http://addiandcassi.com/wordpress/wp-content/uploads/Hempel-Cyclodextrin-Intrathecal-FDAFiling-2010-Aug.pdf (accessed on 20 November 2016).

77. Matsuo, M.; Togawa, M.; Hirabaru, K.; Mochinaga, S.; Narita, A.; Adachi, M.; Egashira, M.; Irie, T.; Ohno, K. Effects of cyclodextrin in two patients with Niemann-Pick Type C disease. Mol. Genet. Metab. 2013, 108, 76-81. [CrossRef] [PubMed]

78. Matsuo, M.; Shraishi, K.; Wada, K.; Ishitsuka, Y.; Doi, H.; Maeda, M.; Mizoguchi, T.; Eto, J.; Mochinaga, S.; Arima, H.; et al. Effects of intracerebroventricular administration of 2-hydroxypropyl- $\beta$-cyclodextrin in a patient with Niemann-Pick Type C disease. Mol. Genet. Metab. Rep. 2014, 1, 391-400. [CrossRef] [PubMed]

79. Yao, J.; Ho, D.; Calingasan, N.Y.; Pipalia, N.H.; Lin, M.T.; Beal, M.F. Neuroprotection by cyclodextrin in cell and mouse models of Alzheimer disease. J. Exp. Med. 2012, 209, 2501-2513. [CrossRef] [PubMed]

(C) 2016 by the author; licensee MDPI, Basel, Switzerland. This article is an open access article distributed under the terms and conditions of the Creative Commons Attribution (CC-BY) license (http://creativecommons.org/licenses/by/4.0/). 